\title{
Contents of Volume 77
}

\section{Number 1, Spring 2018}

\section{CRITICAL FORUM: SOVIET AND POST-SOVIET SEXUALITIES}

Introduction to "Soviet and Post-Soviet Sexualities"

Richard C. M. Mole

Between the Labor Camp and the Clinic: Tema or the Shared Forms of Late Soviet Homosexual Subjectivities Arthur Clech

Soviet Legal and Criminological Debates on the Decriminalization of Homosexuality (1965-75) Rustam Alexander

“That’s Not the Only Reason We Love Him”: Tchaikovskii Reception in Post-Soviet Russia Philip Ross Bullock

Identity, Belonging and Solidarity among Russian-speaking Queer Migrants in Berlin Richard C. M. Mole

ARTICLES

The Maiden and the Wolf: Law, Gender, and Sexual Violence in Imperial Russia Katherine Pickering Antonova and Sergei Antonov

The Making of an Artist as National Hero: The Great Karl Briullov and His Critical Fortunes Katia Dianina

Against the Double Erasure: Georgi Markov's Contribution to the Communist Hypothesis Nikolay Karkov

Split Memory: The Geography of Holocaust Memory and Amnesia in Belarus Anika Walke

REVIEW ESSAY

FEATURED REVIEWS

BOOK REVIEWS

COLLECTED ESSAYS

\section{Number 2, Summer 2018}

\section{ARTICLES}

Psychiatry, Violence, and the Soviet Project of Transformation: A Micro-History of the Perm' Psycho Neurological School-Sanatorium Maria Cristina Galmarini-Kabala

Regionalisms and Imperialisms in the Making of the Russian Far East, 1903-1926 Ivan Sablin and Daniel Sukhan

Riding the Soviet Iron Horse: A Reading of Viktor Turin's Turksib through the Lens of John Ford Ingrid Kleespies

The Shop Window Quality of Things: 1920s Weimar Surface Culture in Nabokov's Korol', dama, valet Luke Parker

In Defense of Native Literature: Writers' Associations, State and the Cult of the Writer in pre-1945 Bulgaria Irina Gigova

Seeing the Bigger Picture: Conspiratorial Revisions of World War II History in Recent Russian Cinema Boris Noordenbos 
FEATURED REVIEWS 4665

BOOK REVIEWS $\quad 480$

REFERENCE BOOKS OF 2016-2017: A SELECTION 560

$\begin{array}{ll}\text { COLLECTED ESSAYS } & 566\end{array}$

$\begin{array}{lr}\text { OTHER BOOKS OF INTEREST } & 571\end{array}$

IN MEMORIAM

$\begin{array}{ll}\text { ERRATA } & 575\end{array}$

Number 3, Fall 2018

\section{CRITICAL FORUM: BEYOND THE IRON CURTAIN, EASTERN EUROPE AND THE}

\section{GLOBAL COLD WAR}

Introduction

Theodora Dragostinova and Małgorzata Fidelis

Polish Economists in Nehru's India: Making Science for the Third World in an Era of De-Stalinization and Decolonization Małgorzata Mazurek

Globalized Socialism, Nationalized Time: Soviet Films, Albanian Subjects, and

Chinese Audiences across the Sino-Soviet Split

Elidor Mëhilli

The Catholic 1968: Poland, Social Justice, and the Global Cold War

Piotr H. Kociski

The "Natural Ally" of the "Developing World": Bulgarian Culture in India and Mexico Theodora Dragostinova

ARTICLES

Modernism Romanced: Imaginary Geography in Jerzy Żuławski’s The Lunar Trilogy Łukasz Wodzyński

Ivo Andrić: Against National Mythopoesis

Marina Antić

Why Women Protest: Insights from Ukraine's EuroMaidan

Olena Nikolayenko and Maria DeCasper

REVIEW ESSAY

FEATURED REVIEWS

FILM REVIEWS

BOOK REVIEWS

COLLECTED ESSAYS

OTHER BOOKS OF INTEREST

IN MEMORIAM

\section{Number 4, Winter 2018}

\section{CRITICAL DISCUSSION FORUM: 1968}

Making a Long Story Longer: Eastern Europe and 1968 as a Global Moment, Fifty Years Later Judit Bodnár

Let's Turn Hegel from His Head onto His Feet: Hopes, Myths, and Memories of the 1960s in Tamás Cseh's Musical Album “A Letter to My Sister” Anna Szemere

Utopias and "Normality”: 1968 Revisited Fifty Years On Jacques Rupnik 
Postmodernity’s Unexpected Arrival: 1968 as Breakdown in Geoculture

Georgi M. Derluguian

Occupy College Street: Student Radicalism in Kolkata in the Sixties

Ranabir Samaddar

\section{MANAGING REGIONAL DIVERSITY}

Andrey Makarychev and Alexandra Yatsyk, Cluster Guest Editors

Russian "Federalism": Illiberal? Imperial? Exceptionalist? Andrey Makarychev and Alexandra Yatsyk

Inside Russia's Imperial Relations: The Social Constitution of Putin-Kadyrov Patronage Julie Wilhelmsen

Kant's Future: Debates about the Identity of Kaliningrad Oblast Miłosz J. Zieliński

Pluralism without Democracy, Vertical without Power: From Gor'kii to Nizhny Novgorod ... and Back?

Andrey Makarychev

ARTICLES

Affirmative Action in the Western Borderlands of the Late Russian Empire? Darius Staliūnas

Russia's Post-Soviet Ideological Terrain: Zvyagintsev's Leviathan and Debates on Authority, Agency, and Authenticity

Susanne Wengle, Christy Monet, and Evgenia Olimpieva

REVIEW ESSAY

FEATURED REVIEWS

FILM REVIEWS

BOOK REVIEWS

DOCTORAL DISSERTATIONS, 2016

COLLECTED ESSAYS

OTHER BOOKS OF INTEREST

IN MEMORIAM

ERRATA

INDEX 


\section{INDEX}

\section{Contributors}

Achilli, Alessandro (review) 3:817

Adler, Nanci (review) 4:1124

Akçam, Taner (review) 2:503

Alexander, Rustam. "Soviet Legal and Criminological Debates on the Decriminalization of Homosexuality (1965-75)" 1:30

Alexopoulos, Golfo (review) 1:264

Alvis, Robert E. 4:1059 4:1059

Anderson, Margaret Lavinia (review) 1:222

Anderson, Sheldon (review) 3:789

Andriewsky, Olga (review) 1:227

Antić, Marina. "Ivo Andrić: Against National Mythopoesis" 3:704

Antonov, Sergei. "The Maiden and the Wolf: Law, Gender, and Sexual Violence in Imperial Russia" 1:99; (review) 2:522

Antonova, Katherine Pickering. "The Maiden and the Wolf: Law, Gender, and Sexual Violence in Imperial Russia” 1:99

Ascher, Abraham (review) 1:259

Baer, Brian James (film review) 2:478

Banac, Ivo (memoriam) 4:1056

Barnes, Teresa (review) 2:535

Barskova, Polina (review) 4:1110

Batalden, Stephen K. (review) 4:1130

Behrends, Jan Claas (review) 4:1137

Belodubrovskaya, Maria (review) 2:549

Berkhoff, Karel C. (review) 4:1107

Bilenky, Serhiy (review) 2:481

Bjelić, Dušan I. (featured review) 1:208

Bjork, Jim (review) 4:1056

Blackwell, Martin J. (review) 1:271

Bodnár, Judit. "Making a Long Story Longer: Eastern Europe and 1968 as a Global Moment, Fifty Years Later" 4:875

Bogert, Ralph (review) 2:510

Borbieva, Noor O’Neill (review) 3:821

Brandenberger, David (featured review) 4:1037

Bremer, Thomas (review) 3:861

Brzostowska-Tereszkiewicz, Tamara (review) 3:856

Bullock, Philip Ross. “'That's Not the Only Reason We Love Him': Tchaikovskii Reception in Post-Soviet Russia” 1:53

Caes, Christopher (review) 3:808

Cassiday, Julie A. (critical review) 3:752

Chatterjee, Choi (featured review) 4:1032

Chebankova, Elena (review) 1:289

Chen, Cheng (review) 2:556

Chitnis, Rajendra (review) 3:816

Choldin, Marianna Tax (memoriam) 4:1055

Chowaniec, Urszula (review) 1:234

Clark, Roland (review) 3:801

Clech, Arthur. "Between the Labor Camp and the Clinic: Tema or the Shared Forms of Late Soviet Homosexual Subjectivities" 1:6

Connelly, John (review) 3:795

Cox, John K. (review) 4:1069

Crockatt, Richard (review) 1:215

Crowe, David M. (featured review) 2:471

Darling, Linda T. (review) 1:216

DeCasper, Maria and Olena Nikolayenko.

"Why Women Protest: Insights from Ukraine's EuroMaidan” 3:726

Demshuk, Andrew (review) 2:492

Derluguian, Georgi M. "Postmodernity's Unexpected Arrival: 1968 as Breakdown in Geoculture” 4:897
Dianina, Katia. "The Making of an Artist as National Hero: The Great Karl Briullov and His Critical Fortunes" 1:122

Dragostinova, Theodora and Małgorzata Fidelis. "Introduction" 3:577

Dragostinova, Theodora. "The 'Natural Ally' of the 'Developing World': Bulgarian Culture in India and Mexico” 3:661

Draitser, Emil (review) 1:232

Dubuisson, Eva-Marie (review) 4:1087

Eden, Jeff (review) 4:1053

Edmondson, Linda (review) 1:249

Eklof, Ben (review) 4:1104

Elias-Bursać, Ellen (review) 1:241

Ellman, Michael (featured review) 2:468

Ely, Christopher (review) 4:1118

Engel, David (featured review) 3:762

Engvall, Johan (featured review) 3:760

Estraikh, Gennady (review) 1:236

Evtuhov, Catherine (review) 2:528

Fawn, Rick (review) 4:1095

Felkay, Andrew (review) 3:825

Field, Deborah A. (review) 1:273

Fleming, Katherine E. (review) 3:774

Freidenreich, Harriet Pass (review) 2:485

Frierson, Cathy A. (review) 1:251

Friesen, Leonard G. (review) 2:530

Gabowitsch, Mischa (review) 4:1097

Galmarini-Kabala, Maria Cristina. "Psychiatry, Violence, and the Soviet Project of Transformation A Micro-History of the Perm' Psycho Neurological School-Sanatorium" 2:307

Gasyna, George (review) 4:1080

Geukjian, Ohannes (review) 2:499

Gibbs, David N. (review) 2:517

Gigova, Irina. "In Defense of Native Literature: Writers' Associations, State and the Cult of the Writer in pre-1945 Bulgaria” 2:417

Gill, Graeme (review) 2:558

Gitelman, Zvi (review) 4:1114

Göcek, Fatma Muge 4:1054

Goddard, Michael N. (review) 4:1079

Górecki, Piotr (review) 1:220

Grant, Susan (review) 1:274

Greble, Emily (review) 3:792

Greene, Robert H. (review) 1:263

Grinberg, Marat (review) 4:1123

Gross, Irena Grudzińska (review) 3:812

Haldey, Olga (review) 3:847

Hale, Henry E. (review) 3:859

Hann, Chris (review) 4:1098

Hanovs, Deniss (review) 3:798

Hansen, Julie (review) 2:540

Hardy, Jeffrey S. (review) 1:269

Harris, Steven E. (review) 1:261

Hartblay, Cassandra (featured review) 3:765

Harte, Tim (memoriam) 1:304

Harte, Tim (review) 3:853

Hartnett, Lynne Ann (review) 1:258

Herold, Kelly (review) 3:848

Heuman, Susan (review) 1:253

Hicks, Jeremy (film review) 4:1048

Hilger, Andreas (featured review) 2:474

Hitchins, Keith (review) 1:225

Hoare, Marko Attila (review) 4:1063

Hodgson, Katharine (review) 4:1126 
Hohler, Susanne (review) 3:831

Hoogenboom, Hilde (review) 2:542

Hooper, Cynthia (review) 3:841

Horwitz, Gordon J. (review) 3:791

Hurst, Mark (review) 4:1134

Iordanova, Dina (film review) 3:772

Iveljić, Iskra (review) 2:509

Jenks, Andrew (review) 3:830

Johnson, A. Ross (review) 4:1071

Jolluck, Katherine R. (review) 2:513

Jones, Jeffrey W. (featured review) 3:769

Jubulis, Mark A. (review) 3:799

Jusová, Iveta (review) 3:780

Kalkandjieva, Daniela (review) 4:1133

Karkov, Nikolay. "Against the Double Erasure: Georgi Markov's Contribution to the Communist Hypothesis" 1:151

Kauffman, Jesse (review) 1:266

Kay, Magdalena (review) 2:506

Kennedy, Michael D. (review) 3:819

Khalid, Adeeb (featured review) 4:1035

Kijek, Kamil (review) 4:1057

Kleespies, Ingrid. "Riding the Soviet Iron Horse: A Reading of Viktor Turin's Turksib through the Lens of John Ford" 2:358

Koller, Sabine (review) 3:851

Kollman, Nancy Shields (review) 2:520

Kolstø, Pål (review) 1:246

Kosicki, Piotr H. "The Catholic 1968: Poland, Social Justice, and the Global Cold War” 3:638

Kostalevsky, Marina (review) 1:277

Kovrig, Bennet (critical review) 1:198

Kowalsky, Sharon A. (review) 4:1060

Kraft, Claudia (review) 3:775

Krom, Mikhail (review) 4:1100

Krutikov, Mikhail (review) 4:1121

Kuehnast, Kathleen (review) 1:295

Kumar, Krishan (review) 3:828

Kurchanova, Natasha (review) 1:284

Kushkova, Anna (review) 3:839

Láníček, Jan (review) 4:1062

Libman, Alexander (review) 1:287

Light, Nathan (review) 1:244

Lih, Lars T. (review) 1:213

Lindstedt, Iwona (review) 3:815

Makarychev, Andrey and Alexandra Yatsyk. "Russian 'Federalism': Illiberal? Imperial? Exceptionalist?" 4:912

Makarychev, Andrey. "Pluralism without Democracy, Vertical without Power: From Gorky to Nizhnii Novgorod . . . and Back?" 4:957

Manchester, Laurie (review) 2:531

Mandelstam Balzer, Marjorie (review) 4:1128

Martin, Barbara (memoriam) 2:573

Martinsen, Deborah A. (review) 4:1115

Mazurek, Małgorzata. "Polish Economists in Nehru's India: Making Science for the Third World in an Era of De-Stalinization and Decolonization" 3:588

McCormick, Robert B. (review) 3:794

McGlinchey, Eric (review) 4:1090

McMeekin, Sean (review) 1:257

McQuillen, Colleen (review) 3:854

Mëhilli, Elidor. "Globalized Socialism, Nationalized

Time: Soviet Films, Albanian Subjects, and Chinese Audiences across the Sino-Soviet Split” 3:611

Merchant, John (review) 1:235

Mesropova, Olga (review) 4:1127

Mick, Christoph (review) 3:786

Milkova, Stiliana (review) 2:543

Miller, Alexey (review) 2:480
Mole, Richard C. M. "Introduction to 'Soviet and PostSoviet Sexualities”” 1:1; “Identity, Belonging and Solidarity among Russian-speaking Queer Migrants in Berlin" 1:77

Mole, Richard C. M. (film review) 4:1049

Monet, Christy, Susanne Wengle, and Evgenia Olimpieva. "Russia’s Post-Soviet Ideological Terrain: Zvyagintsev's Leviathan and Debates on $\mathrm{Au}$ thority, Agency, and Authenticity" 4:998

Montgomery, David W. (review) 4:1086

Moraski, Bryon J. (review) 1:291

Morozov, Viacheslav (review) 3:858

Mulry, David (review) 2:507

Murray, Natalia (review) 3:844

Naroditskaya, Inna (review) 1:275

Natkovich, Svetlana (review) 4:1073

Naydan, Michael M. (memoriam) 4:1058

Nelson, Robert (review) 1:226

Newman, John Paul (featured review) 4:1041

Nikolayenko, Olena and Maria DeCasper. "Why Women Protest: Insights from Ukraine's EuroMaidan” 3:726; (review) 4:1075

Noordenbos, Boris. "Seeing the Bigger Picture: Conspiratorial Revisions of World War II History in Recent Russian Cinema” 2:441

Offord, Derek (review) 3:835

Oldfield, Jonathan (review) 2:553

Olimpieva, Evgenia, Susanne Wengle, and Christy Monet. "Russia's Post-Soviet Ideological Terrain: Zvyagintsev's Leviathan and Debates on Authority, Agency, and Authenticity" 4:998

Oklot, Michal (review) 4:1076

O’Neill, Bruce (review) 3:860

Osokina, Elena A. (review) 2:538

Oukaderova, Lida (review) 3:843

Paces, Cynthia J. (review) 3:781

Paloff, Benjamin (review) 3:813

Parker, Luke. "The Shop Window Quality of Things: 1920s Weimar Surface Culture in Nabokov's Korol', dama, valet” 2:390

Parsons, Michelle (review) 1:292

Petkov, Kiril (review) 3:779

Pennington, Reina (review) 2:489

Perlina, Nina (review) 1:278

Peters, Benjamin (review) 4:1136

Petrescu, Dragos (review) 3:804

Petrone, Karen (review) 2:524

Pienkos, Donald E. (review) 2:490

Pohl, Michaela (review) 4:1088

Poole, Randall A. (review) 4:1131

Porter-Szucs, Brian (review) 1:229

Pörzgen, Yvonne (review) 1:239

Potapova, Natalia 4:1044

Prais, Lea (review) 2:494

Ransel, David L. (review) 4:1101

Rasmussen, Ljerka V. (review) 3:809

Rayfield, Donald (review) 2:545

Razsa, Maple (film review) 4:1050

Read, Christopher (review) 4:1111

Reese, Kevin (review) 2:550

Reifowitz, Ian (review) 2:486

Reinert, Stephen W. (review) 3:805

Rethmann, Petra (review) 2:552

Retish, Aaron B. (review) 1:250

Rewakowicz, Maria G. (critical review) 4:1025

Riegg, Stephen B. (review) 4:1103

Rode, Dagmara (review) 2:504

Rogel, Carole (review) 2:497

Rogers, Douglas (review) 2:555

Rothstein, Robert A. (review) 3:845

Roudometof, Victor (review) 1:212 
Rozenblit, Marsha L. (featured review) 2:465

Rudova, Larissa (review) 1:281

Rupnik, Jacques. “Utopias and 'Normality’: 1968 Revisited Fifty Years On" 4:890

Rupprecht, Tobias (review) 3:777

Ruthchild, Rochelle Goldberg (review) 3:838

Ryazanova-Clarke, Lara (review) 1:282

Sablin, Ivan and Daniel Sukhan. "Regionalisms and Imperialisms in the Making of the Russian Far East, 1903-1926" 2:333

Safran, Gabriella (review) 2:546

Samaddar, Ranabir. "Occupy College Street: Student Radicalism in Kolkata in the Sixties" 4:904

Sanborn, Joshua (review) 4:1106

Sanders, Thomas (review) 3:833

Saunders, Robert A. (review) 1:286

Shallcross, Bożena (review) 1:238

Shelley, Louise (review) 2:539

Shepherd, Ben (review) 4:1065

Shiraev, Eric (review) 4:1112

Shkandrij, Myroslav (review) 3:810

Skinner, Barbara (review) 2:483

Smele, Jonathan D. (review) 3:834

Smith, Jeremy (review) 2:502

Smith, Kathleen (memoriam) 2:573

Smith, S.A. (featured review) 1:205

Snel, Guido (review) 1:242

Spieker, Sven (review) 4:1078

Staliunas, Darius (review) 2:500; "Affirmative Action in the Western Borderlands of the Late Russian Empire?” 4:978

Stanziani, Alessandro (review) 3:827

Starks, Tricia (review) 1:267

Steinwedel, Charles (review) 2:526

Stephan, John J. (review) 2:525

Stolarski, Christopher (review) 2:533

Stone, David R. (review) 2:534

Stronski, Paul (review) 4:1108

Strukov, Vlad (review) 2:547

Sukhan, Daniel and Ivan Sablin. "Regionalisms and Imperialisms in the Making of the Russian Far East, 1903-1926" 2:333

Suslov, Mikhail (review) 1:293

Swanson, John C. (review) 3:783

Szemere, Anna (review) 2:495; "Let's Turn Hegel from His Head onto His Feet: Hopes, Myths, and Memories of the 1960s in Tamás Cseh's Musical Album ‘A Letter to My Sister”" 4:881

Török, Borbala Zsuzsanna (review) 1:218

Thaler, Peter (review) 1:223

Thomas, Alfred (review) 2:512

Thomas, Alun (review) 1:270

Toma, Stefánia (review) 1:247

Tromly, Benjamin (review) 3:837

Trubeta, Sevasti (review) 3:802

Tsygankov, Andrei P. (review) 2:516

Varga-Harris, Christine (review) 3:850

Verdery, Katherine (review) 4:1093

Vezovnik, Andreja (review) 1:230

Viise, Michelle R. (review) 3:784

Waldron, Peter (review) 1:255

Walke, Anika. "Split Memory: The Geography of Holocaust Memory and Amnesia in Belarus" 1:174

Walker, Edward W. (review) 3:824

Wengle, Susanne, Evgenia Olimpieva, and Christy Monet. "Russia's Post-Soviet Ideological Terrain: Zvyagintsev's Leviathan and Debates on Authority, Agency, and Authenticity" 4:998

Werlen, Benno (review) 3:776

West, Sally (review) 1:254
Wezel, Katja (review) 4:1072

White, Elizabeth (review) 2:488

Whitehead, Claire (review) 4:1117

Wilhelmsen, Julie. “Inside Russia’s Imperial Relations: The Social Constitution of Putin-Kadyrov Patronage" 4:919

Willimott, Andy (review) 4:1066

Witts, Noel (review) 4:1084

Wodzyński, Łukasz. "Modernism Romanced: Imaginary Geography in Jerzy Żuławski's The Lunar Trilogy" 3:685

Wojdon, Joanna (review) 3:788

Wolczuk, Kataryna (review) 2:515

Woodward, Susan L. (review) 4:1094

Yatsyk, Alexandra and Andrey Makarychev. "Russian 'Federalism': Illiberal? Imperial? Exceptionalist?” 4:912

Yordanov, Radoslav (review) 3:796; (review) 4:1068

Zanca, Russell (review) 3:822

Zhuk, Sergei I. (review) 2:536

Zieliński, Miłosz J. "Kant’s Future: Debates about the Identity of Kaliningrad Oblast" 4:937

Zorić, Vladimir (review) 4:1082

\section{In Memoriam}

Allen, Elizabeth Cheresh (Tim Harte) 1:304

Farris, June Pachuta (Marianna Tax Choldin) 4:1055

Prusin, Alexander (Orel Beilinson) 3:870

Roginskii, Arsenii Borisovich (Barbara Martin and Kathleen Smith) 2:573

Rubchak, Bohgdan (Michael M. Naydan) 4:1058

Wandycz, Piotr S. (Ivo Banac) 4:1056

\section{Films Reviewed}

Grlić, Rajko dir. Ustav Republike Hrvatske: Ljubavna priča o mržnji (Dina Iordanova) 3:772

Kolmane, Inara, dir. Double Life: A Short History of Sex in the USSR (Richard C. M. Mole) 4:1049

Loznitsa, Sergei, dir. Austerlitz (Jeremy Hicks) 4:1048

Rudnitskaya, Alina, dir. Victory Day (Brian James Baer) 2:478

Turajlić, Mila, dir. Druga strana svega (The Other Side of Everything) (Maple Razsa) 4:1050

\section{Books Reviewed}

Akhrarkhodjaeva, Nozima. The Instrumentalisation of Mass Media in Electoral Authoritarian Regimes: Evidence from Russia's Presidential Election Campaigns of 2000 and 2008 (Mikhail Suslov) 1:293

Alexopoulos, Golfo. Illness and Inhumanity in Stalin's Gulag (Jeffrey S. Hardy) 1:269

Altstadt, Audrey L. Frustrated Democracy in Post-Soviet Azerbaijan (Ohannes Geukjian) 2:499

Altstadt, Audrey L. The Politics of Culture in Soviet Azerbaijan, 1920-1940 (Jeremy Smith) 2:502

Mark Andryczyk, ed. The White Chalk of Days: The Contemporary Ukrainian Literature Series Anthology (Maria G. Rewakowicz) 4:1025

Antić, Ana. Therapeutic Fascism: Experiencing the Violence of the Nazi New Order (Dušan I. Bjelić) 1:208

Antonych, Bohdan Ihor. The Grand Harmony, trans. Michael M. Naydan (Alessandro Achilli) 3:817

Archer, Roy, Igor Duda, and Paul Stubbs, eds. Social Inequalities and Discontent in Yugoslav Socialism (Andreja Vezovnik) 1:230

Artwińska, Anna, Bartłomiej Starnawski, and Grzegorz Wołowiec, eds., Studies on Socialist Realism: The Polish View (Yvonne Pörzgen) 1:239 
Badcock, Sarah. A Prison without Walls? Eastern Siberian Exile in the Last Years of Tsarism (Cathy A. Frierson) 1:251

Baker, Catherine, ed. Gender in 20th Century Eastern Europe and the USSR (Harriet Pass Freidenreich) 2:485

Bakić, Dragan. Britain and Interwar Danubian Europe: Foreign Policy and Security Challenges, 1919-1936 (Bennett Kovrig) 1:198

Barelkowski, Matthias, Claudia Kraft, and Isabel Röskau-Rydel, eds. Zwischen Geschlecht und Nation. Interdependenzen und Interaktionen in der multiethnischen Gesellschaft Polens im 19. und 20. Jahrhundert (Robert Nelson) 1:226

Barskova, Polina. Besieged Leningrad: Aesthetic Responses to Urban Disaster (Katharine Hodgson) 4:1126

Bassin, Mark and Mikhail Suslov, eds. Eurasia 2.0: Russian Geopolitics in the Age of New Media (Robert A. Saunders) 1:286

Beer, Daniel. The House of the Dead: Siberian Exile under the Tsars (Aaron B. Retish) 1:250

Beneš, Jakub S. Workers and Nationalism: Czech and German Social Democracy in Habsburg Austria, 1890-1918 (Marsha L. Rozenblit) 2:465

Bergelson, David. Judgment: A Novel, trans. Harriet Murav and Sasha Senderovich (Mikhail Krutikov) 4:1121

Beresniova, Christine. Holocaust Education in Lithuania: Community, Conflict, and the Making of Civil Society (Darius Staliunas) 2:500

Bergholz, Max. Violence as a Generative Force: Identity, Nationalism, and Memory in a Balkan Community (Robert B. McCormick) 3:794

Bernstein, Seth. Raised under Stalin: Young Communists and the Defense of Socialism (David Brandenberger) 4:1037

Bertelsen, Olga. Revolution and War in Contemporary Ukraine: The Challenge of Change (Pål Kolstø) 1:246

Beuerle, Benjamin. Russlands Westen: Westorientierung und reformgesetzgebung im ausgehenden Zarenreich 1905-1917 (Susan Heuman) 1:253

Beumers, Birgit. Aleksandr Sokurov: Russian Ark (Maria Belodubrovskaya) 2:549

Beumers, Birgit, Alexander Etkind, Olga Gurova, and Sanna Turoma, eds. Cultural Forms of Protest in Russia (Julie A. Cassiday) 3:752

Beyer, Judith. The Force of Custom: Law and the Ordering of Everyday Life in Kyrgyzstan (Kathleen Kuehnast) 1:295

Biskupski, M.B.B. War and Diplomacy in East and West A Biography of Józef Retinger (Sheldon Anderson) 3:7879

Bjork, James, Tomasz Kamusella, Tim Wilson, and Anna Novikov, eds. Creating Nationality in Central Europe, 1800-1950: Modernity, Violence, and (Be) longing in Upper Silesia (Andrew Demshuk) 2:492

Blakkisrud, Helge and Pål Kolstø. The New Russian Nationalism: Imperialism, Ethnicity and Authoritarianism, 2000-15 (Cheng Chen) 2:556

Blobaum, Robert. A Minor Apocalypse: Warsaw during the First World War (Christoph Mick) 3:786

Boeckh, Katrin and Sabine Rutar, eds. The Wars of Yesterday: The Balkan Wars and the Emergence of Modern Military Conflict, 1912-1913 (John Paul Newman) 4:1041

Bogdan, Jolan. Performative Contradiction and the Romanian Revolution (Dragoș Petrescu) 3:804

Bohn, Thomas M., Rayk Einax, and Stefan Rohdewald, eds. Vlad der Pfähler-Dracula: Tyrann oder Volkstri bun? (Stephen W. Reinert) 3:805
Brandišauskas, Donatas. Leaving Footprints in the Taiga: Luck, Spirits and Ambivalence among the Siberian Orochen Reindeer Herders and Hunters (Petra Rethmann) 2:552

Brenton, Tony, ed. Was Revolution Inevitable?: Turning Points of the Russian Revolution (Abraham Ascher) 1:259

Brodsky, G.W. Stephen. Joseph Conrad's Polish Soul: Realms of Memory and Self, ed. George Z. Gasyna (David Mulry) 2:507

Bryzgel, Amy. Performance Art in Eastern Europe since 1960 (Sven Spieker) 4:1078

Burgess, John P. Holy Rus': The Rebirth of Orthodoxy in the New Russia (Thomas Bremer) 3:861

Bushnell, John. Russian Peasant Women Who Refused to Marry: Spasovite Old Believers in the Eighteenth and Nineteenth Centuries (David L. Ransel) 4:1101

Caldwell, Melissa. Living Faithfully in an Unjust World: Compassionate Care in Russia (Bruce O’Neill) 3:860

Câmpeanu, Remus, Ladislau Gyémánt, Anton Dörner, and Florin Mureşan, eds., Conscripţia fiscală $a$ Transilvaniei din anul 1750 (Keith Hitchins) 1:225

Carleton, Gregory. Russia: The Story of War (Karen Petrone) 2:524

Carr, Maureen, Severine Neff, Gretchen Horlacher, and John Reef, eds. The Rite of Spring at 100 (Olga Haldey) 3:847

Charap, Samuel and Timothy J. Colton. Everyone Loses: The Ukraine Crisis and the Ruinous Contest for PostSoviet Eurasia (Andrei P. Tsygankov) 2:516

Chernev, Borislav. Twilight of Empire: The Brest-Litovsk Conference and the Remaking of East-Central Europe, 1917-1918 (Bennett Kovrig) 1:198

Colton, Timothy J. and Samuel Charap. Everyone Loses: The Ukraine Crisis and the Ruinous Contest for PostSoviet Eurasia (Andrei P. Tsygankov) 2:516

David-Fox, Michael, ed. The Soviet Gulag: Evidence, Interpretation, and Comparison (Cynthia Hooper) 3:841

Dittmar Dahlmann, Klaus Heller, and Jurij A. Petrov, eds. Protestanten und Altgläubige-Juden und Muslime: Die ethno-konfessionelle Struktur der russländischen Unternehmerschaft vor 1914 (Catherine Evtuhov) 2:528

Dick, C.J. From Victory to Stalemate: The Western Front, Summer 1944 (Jesse Kauffman) 1:266

Dick, C.J. From Defeat to Victory: The Eastern Front, Summer 1944 (Jesse Kauffman) 1:266

Djurić, Dubravka and Biljana D. Obradović eds., Cat Painters: An Anthology of Contemporary Serbian Poetry (Ellen Elias-Bursać) 1:241

Domdey, Jana, Gesine Drews-Sylla, and Justyna Gołąbek, eds. AnOther Africa? (Post-)Koloniale Afrikaimaginationen im russischen, polnischen und deutschen Kontext (Radoslav Yordanov) 3:796

Dörner, Anton, Ladislau Gyémánt, Remus Câmpeanu, and Florin Mureşan, eds. Conscripţia fiscală a Transilvaniei din anul 1750 (Keith Hitchins) 1:225

Dragostinova, Theodora and Yana Hashamova, eds. Beyond Mosque, Church and State: Alternative Narratives of the Nation in the Balkans (Victor Roudometof) 1:212

Drews-Sylla, Gesine, Jana Domdey, and Justyna Gołąbek, eds. AnOther Africa? (Post-)Koloniale Afrikaimaginationen im russischen, polnischen und deutschen Kontext (Radoslav Yordanov) 3:796

Dubuisson, Eva-Marie. Living Language in Kazakhstan: The Dialogic Emergence of an Ancestral Worldview (David W. Montgomery) 4:1086 
Duda, Igor, Roy Archer and Paul Stubbs, eds. Social Inequalities and Discontent in Yugoslav Socialism (Andreja Vezovnik) 1:230

Edele, Mark. Stalin's Defectors: How Red Army Soldiers became Hitler's Collaborators, 1941-1945 (Karel C. Berkhoff) 4:1107

Einax, Rayk, Thomas M. Bohn, and Stefan Rohdewald, eds. Vlad der Pfähler-Dracula: Tyrann oder Volkstribun? (Stephen W. Reinert) 3:805

Ely, Christopher. Underground Petersburg: Radical Populism, Urban Space, and the Tactics of Subversion in Reform-Era Russia (Lynne Ann Hartnett) 1:258

Enticott, Peter. The Russian Liberals and the 1905 Revolution (Jonathan D. Smele) 3:834

Etkind, Alexander, Birgit Beumers, Olga Gurova, and Sanna Turoma, eds. Cultural Forms of Protest in Russia (Julie A. Cassiday) 3:752

Evdokimova, Svetlana and Vladimir Golstein, eds. Dostoevsky Beyond Dostoevsky: Science, Religion, Philosophy (Nina Perlina) 1:278

Féaux de la Croix, Jeanne. Iconic Places in Central Asia: The Moral Geography of Dams, Pastures, and Holy Sites (Eva-Marie Dubuisson) 4:1087

Feinberg, Melissa. Curtain of Lies: The Battle over Truth in Stalinist Eastern Europe (A. Ross Johnson) 4:1071

Feldman, Walter Zev. Klezmer: Music, History, and Memory (Robert A. Rothstein) 3:845

Finke, Michael C. and Michael Holquist, eds. Approaches to Teaching the Works of Anton Chekhov (Donald Rayfield) 2:545

First, Joshua. Sergei Paradjanov: Shadows of Forgotten Ancestors (Maria Belodubrovskaya) 2:549

Fleron, Frederic J. Jr. Russian Studies and Comparative Politics: Views from Metatheory and Middle-Range Theory (Bryon J. Moraski) 1:291

Formakov, Arsenii. Gulag Letters, ed. and Trans. Emily D. Johnson (Nanci Adler) 4:1124

Fowler, Mayhill C. Beau Monde on Empire's Edge: State and Stage in Soviet Ukraine (Myroslav Shkandrij) 3:810

Franaszek, Andrzej. Miłosz: A Biography, Ed. and trans. Aleksandra and Michael Parker (Magdalena Kay) 2:506

Frančíková, Dáša. Women as Essential Citizens in the Czech National Movement: The Making of the Modern Czech Community (Iveta Jusová) 3:780

Frenkel, Ann, Gwido Zlatkes, and Paweł Sowiński, eds. Duplicator Underground: The Independent Publish ing Industry in Communist Poland 1976-89 (Joanna Wojdon) 3:788

Fürst, Juliane and Josie McLellan, eds. Dropping Out of Socialism: The Creation of Alternative Spheres in the Soviet Bloc (Anna Szemere) 2:495

Fusso, Susanne. Editing Turgenev, Dostoevsky \& Tolstoy: Mikhail Katkov and the Great Russian Novel (Deborah A. Martinsen) 4:1115

Galmarini-Kabala, Maria Cristina. The Right to be Helped: Deviance, Entitlement, and the Soviet Moral Order (Tricia Starks) 1:267

Garstka, Christoph. Geschichte und kommunistische Gegenwart: Historiosophische Positionen und ihre narrative Präsentation in Essay und Roman der Volksrepublik Polen (Christopher Caes) 3:808

Georgescu, Tudor. The Eugenic Fortress: The Transylvanian Saxon Experiment in Interwar Romania (Sevasti Trubeta) 3:802

Ghodsee, Kristen. Red Hangover: Legacies of TwentiethCentury Communism (Katherine Verdery) 4:1093

Glebov, Sergey. From Empire to Russia: Politics, Scholarship, and Ideology in Russian Eurasianism, 1920s1930s (Derek Offord) 3:835
Goehrke, Carsten. Lebenswelten Sibiriens: Aus Natur und Geschichte des Jenissei-Stromlandes (John J. Stephan) 2:525

Gołąbek, Justyna, Jana Domdey, and Gesine DrewsSylla, eds., AnOther Africa? (Post-)Koloniale Afrikaimaginationen im russischen, polnischen und deutschen Kontext (Radoslav Yordanov) 3:796

Goldstein, Ivo and Slavko Goldstein. The Holocaust in Croatia (Marko Attila Hoare) 4:1063

Goldstein, Slavko and Ivo Goldstein. The Holocaust in Croatia (Marko Attila Hoare) 4:1063

Golstein, Vladimir and Svetlana Evdokimova, eds. Dostoevsky Beyond Dostoevsky: Science, Religion, Philosophy (Nina Perlina) 1:278

Goossen, Benjamin W. Chosen Nation. Mennonites and Germany in the Global Era (Leonard G. Friesen) 2:530

Grinberg, Marat Aleksandr Askoldov: The Commissar (Maria Belodubrovskaya) 2:549

Grlić, Rajko, dir. Ustav Republike Hrvatske: Ljubavna priča o mržnji (Dina Iordanova) 3:772

Gurova, Olga, Birgit Beumers, Alexander Etkind, and Sanna Turoma, eds. Cultural Forms of Protest in Russia (Julie A. Cassiday) 3:752

Gyémánt, Ladislau, Remus Câmpeanu, Anton Dörner, and Florin Mureşan, eds. Conscripţia fiscală a Transilvaniei din anul 1750 (Keith Hitchins) 1:225

Hajtó, Vera. Milk Sauce and Paprika: Migration, Childhood and Memories of the Interwar Belgian-Hungarian Child Relief Project (Elizabeth White) 2:488

Hardy, Jeffrey S. The Gulag after Stalin: Redefining Punishment in Khrushchev's Soviet Union, 1953-1964 (Alun Thomas) 1:270

Harris, Robbin P. Storytelling in Siberia: The Olonkho Epic in a Changing World (Marjorie Mandelstam Balzer) 4:1128

Hasegawa, Tsuyoshi. Crime and Punishment in the Russian Revolution: Mob Justice and Police in Petrograd (Joshua Sanborn) 4:1106

Hashamova, Yana and Theodora Dragostinova, eds. Beyond Mosque, Church and State: Alternative Narratives of the Nation in the Balkans (Victor Roudometof) 1:212

Heftrich, Urs, Robert Jacobs, Bettina Kaibach, and Karoline Thaidigsmann, eds. Images of Rupture between East and West: The Perception of Auschwitz and Hiroshima in Eastern European Arts and Media (Irena Grudzińska Gross) 3:812

Heinzen, James. The Art of the Bribe. Corruption Under Stalin, 1943-1953 (Elena A. Osokina) 2:538

Heller, Klaus, Dittmar Dahlmann, and Jurij A. Petrov, eds. Protestanten und Altgläubige-Juden und Muslime: Die ethno-konfessionelle Struktur der russländischen Unternehmerschaft vor 1914 (Catherine Evtuhov) 2:528

Henderson, Robert. Vladimir Burtsev and the Struggle for a Free Russia: A revolutionary in the Time of Tsarism and Bolshevism (Ben Eklof) 4:1104

Hendley, Kathryn. Everyday Law in Russia (Louise Shelley) 2:539

Hennings, Jan. Russia and Courtly Europe: Ritual and the Culture of Diplomacy, 1648-1725 (Nancy Shields Kollman) 2:520

Hill, Alexander. The Red Army and the Second World War (David R. Stone) 2:534

Hodgson, Katharine, Joanne Shelton, and Alexandra Smith, eds. Twentieth-Century Russian Poetry: Reinventing the Canon (Marat Grinberg) 4:1123

Hohler, Susanne. Fascism in Manchuria: The SovietChina Encounter in the 1930s (Laurie Manchester) 2:531 
Holquist, Michael and Michael C. Finke eds. Approaches to Teaching the Works of Anton Chekhov (Donald Rayfield) 2:545

Horlacher, Gretchen, Severine Neff, Maureen Carr, and John Reef, eds. The Rite of Spring at 100 (Olga Haldey) 3:847

Horowitz, Brian. The Russian-Jewish Tradition: Intellec tuals, Historians, Revolutionaries (Gabriella Safran) 2:546

Horváth, Sándor. Stalinism Reloaded: Everyday Life in Stalin-City, Hungary (Andy Willimott) 4:1066

Huhn, Ingeborg. Johann Gottfried Wetzstein. Orientalist und preußischer Konsul im osmanischen Syrien (1849-1861) (Margaret Lavinia Anderson) 1:222

Insdorf, Annette. Intimations: The Cinema of Wojciech Has (Michael N. Goddard) 4:1079

Irvin-Erickson, Douglas. Raphaël Lemkin and the Con cept of Genocide (Claudia Kraft) 3:775

Ivanova, Anna. Magaziny "Berezka”: Paradoksy potre bleniia $v$ pozdnem SSSR (Sergei I. Zhuk) 2:536

Jacobs, Robert, Urs Heftrich, Bettina Kaibach, and Karo line Thaidigsmann, eds. Images of Rupture between East and West: The Perception of Auschwitz and Hiroshima in Eastern European Arts and Media (Irena Grudzińska Gross) 3:812

Jacobsson, Kerstin, and Elżbieta Korolczuk, eds. Civil Society Revisited: Lessons from Poland (Michael D. Kennedy) 3:819

Jakelski, Lisa. Making New Music in Cold War Poland: The Warsaw Autumn Festival, 1956-1968 (Iwona Lindstedt) 3:815

Jankevičiūtè, Giedrè and Rasutė Žukienè, eds. The Art of Identity and Memory: Toward a Cultural History of the Two World Wars in Lithuania (Michelle R. Viise) 3:784

Jaritz, Gerhard and Katalin Szende, eds. Medieval East Central Europe in a Comparative Perspective: From Frontier Zones to Lands in Focus (Piotr Górecki) $1: 220$

Jones, Pauline, ed. Islam, Society, and Politics in Central Asia (Eric McGlinchey) 4:1090

Juzefovičs, Jānis. Broadcasting and National Imagination in Post-Communist Latvia. Defining the Nation, Defining Public Television (Katja Wezel) 4:1072

Kaibach, Bettina, Urs Heftrich, Robert Jacobs, and Karoline Thaidigsmann, eds. Images of Rupture between East and West: The Perception of Auschwitz and Hiroshima in Eastern European Arts and Media (Irena Grudzińska Gross) 3:812

Kamusella, Tomasz, James Bjork, Tim Wilson, and Anna Novikov, eds. Creating Nationality in Central Europe, 1800-1950: Modernity, Violence, and (Be) longing in Upper Silesia (Andrew Demshuk) 2:492

Kaplan, Vera. Historians and Historical Societies in the Public Life of Imperial Russia (Thomas Sanders) 3:833

Katz, Elena and Judith Pallot. Waiting at the Prison Gate: Women, Identity and the Russian Penal System (Julie Hansen) 2:540

Kelly, Catriona. Socialist Churches: Radical Secularization and the Preservation of the Past in Petrograd and Leningrad, 1918-1988 (Robert H. Greene) 1: 263

Kenney, Padraic Dance in Chains: Political Imprisonment in the Modern World (Choi Chatterjee) 4:1032

Keough, Leyla J. Worker-Mothers on the Margins of Europe: Gender and Migration between Moldova and Istanbul (Katherine R. Jolluck) 2:513

Kijek, Kamil. Dzieci modernizmu: Świadomość, kultura i socjalizacja polityczna młodzieży żydowskiej w II Rzeczypospolitej (David Engel) 3:762

Kleinmann, Yvonne, Stephan Stach, and Tracie L. Wilson, eds. Religion in the Mirror of Law: Eastern
European Perspectives from the Early Modern Period to 1939 (Barbara Skinner) 2:483

Knight, Robert. Slavs in Post-Nazi Austria: Carinthian Slovenes and the Politics of Assimilation, 1945-1960 (John Connelly) 3:795

Kollmann, Nancy Shields. The Russian Empire: 1450 1801 (Alessandro Stanziani) 3:827

Kolonitskii, Boris. "Tovarishch Kerenskii”: Antimonarkhicheskaia revoliutsiia i formirovaniia kul' ta "vozhdia naroda," mart-iiun' 1917 goda (S. A. Smith) 1:205

Kolstø, Pål and Helge Blakkisrud. The New Russian Nationalism: Imperialism, Ethnicity and Authoritarianism, 2000-15 (Cheng Chen) 2:556

Korolczuk, Elżbieta, and Kerstin Jacobsson, eds. Civil Society Revisited: Lessons from Poland (Michael D. Kennedy) 3:819

Kosharovsky, Yuli. “We are Jews Again”: Jewish Activism in the Soviet Union (Zvi Gitelman) 4:1114

Kosicki, Piotr H. ed. Vatican II Behind the Iron Curtain (Brian Porter-Szucs) 1:229

Kot, Joanna. Complicating the Female Subject: Gender, National Myths and Genre in Polish Women's InterWar Drama (Urszula Chowaniec) 1:234

Kraft, Claudia, Barelkowski, Matthias, and Isabel Röskau-Rydel, eds. Zwischen Geschlecht und Nation. Interdependenzen und Interaktionen in der multiethnischen Gesellschaft Polens im 19. und 20. Jahrhundert (Robert Nelson) 1:226

Kuc, Kamila. Visions of Avant-Garde Film: Polish Cinematic Experiments from Expressionism to Constructivism (Dagmara Rode) 2:504

Kumar, Krishan. Visions of Empire: How Five Imperial Regimes Shaped the World (Alexey Miller) 2:480

Kurbanovskii, Aleksei. Khishchnyi Glaz: Novye ocherk po arkheologii vizual' nosti (Natasha Kurchanova) $1: 284$

La Guma, Alex. A Soviet Journey, A Critical Annotated Edition, Christopher Lee, ed. (Teresa Barnes) 2:535

Lagutina, Maria L. and Nataliya A. Vasilyeva. The Rus sian Project of Eurasian Integration: Geopolitical Prospects (Alexander Libman) 1:287

Lánícek, Jan. Arnošt Frischer and the Jewish Politics of Early 20th-Century Europe (Ian Reifowitz) 2:486

Lapina-Kratasyuk, E. G., O. V. Moroz, and E. G. Nim, eds. Nastroika iazyka: Upravlenie kommunikatiiami na postsovetskom prostranstve (Lara RyazanovaClarke) 1:282

Laruelle, Marlene, ed. Kazakhstan in the Making: Legitimacy, Symbols, and Social Changes (Michaela Pohl) 4:1088

Levchenko, Ian and Igor' Pil'shchikov, eds. Epokha "ostraneniia": Russkii formalizm i sovremennoe gumanitarnoe znanie. Kollektivnaia monografia ( $\mathrm{Ta}$ mara Brzostowska-Tereszkiewicz) 3:856

Levi, Scott C. The Rise and Fall of Khoqand: Central Asia in the Global Age, 1709-1876 (Jeff Eden) 4:1053

Lichtenstein, Tatjana. Zionists in Interwar Czechoslovakia: Minority Nationalism and the Politics of Belong ing (Jan Láníček) 4:1062

Lovell, Stephen. Russia in the Microphone Age: A History of Soviet Radio, 1919-1970 (Christopher Stolarski) 2:533

Łukasiewicz, Sławomir. Third Europe: Polish Federalist Thought in the United States, 1940-1970s, trans. Witold Zbirohowski-Kościa (Donald E. Pienkos) 2:490

Magyar, Bálint, and Júlia Vásárhelyi, eds., Twenty-Five Sides of a Post-communist Mafia State, trans. Bálint Bethlenfalvy, Steven Nelson, Kata Paulin, Ágnes Simon, Anna Szemere, Robert Young, and Frank T. Zsigó (Andrew Felkay) 3:825 
Maksymchuk, Oksana and Max Rosochinsky, eds. Words for War: New Poems from Ukraine (Maria G. Rewakowicz) 4:1025

Malewska-Szałgin, Anna. Social Imaginaries of the State and Central Authority in Polish Highland Villages, 1999-2005, trans. Aniela Korzeniowska and Stefan Sikora (Chris Hann) 4:1098

Marasinova, Elena. "Zakon" $i$ "grazhdanin" $v$ Rossii vtoroi poloviny XVIII veka: Ocherki istorii obshchestvennogo soznaniia (Natalia Potapova) 4:1044

Martin, Sean, ed. and trans. For the Good of the Nation: Institutions for Jewish Children in Interwar Poland. A Documentary History (Kamil Kijek) 4:1057

Martinovich, Viktor. Rodina: Mark Shagal v Vitebske (Natalia Murray) 3:844

Masur, Matthew, ed. Understanding and Teaching the Cold War (Richard Crockatt) 1:215

Matsuzato, Kimitaka. Russia and Its Northeast Asian Neighbors: China, Japan, and Korea, 1858-1945 (Susanne Hohler) 3:831

McLellan, Josie and Juliane Fürst, eds. Dropping Out of Socialism: The Creation of Alternative Spheres in the Soviet Bloc (Anna Szemere) 2:495

McMahon, Patrice C. The NGO Game: Post-Conflict Peacebuilding in the Balkans and the Beyond (Susan L. Woodward) 4:1094

Meerovich, Mark Grigor'evich. Gradostroitel' naia Politika v SSSR, 1917-1929: Ot goroda-sada k vedomstvennomu rabochemu poselku (Christine VargaHarris) 3:850

Mehmeti, Leandrit I. and Branislav Radeliic, eds. Kosovo and Serbia: Contested Options and Shared Consequences (David N. Gibbs) 2:517

Michelson, Patrick Lally. Beyond the Monastery Walls: The Ascetic Revolution in Russian Orthodox Thought, 1814-1914 (Stephen K. Batalden) 4:1130

Michlic, Joanna Beata, ed. Jewish Families in Europe, 1939-Present: History, Representation, and Memory (Lea Prais) 2:494

Mickenberg, Julia. American Girls in Red Russia (Rochelle Goldberg Ruthchild) 3:838

Mickiewicz, Adam. Forefather's Eve, Trans. Charles S. Kraszewski (John Merchant) 1:235

Mihailovic, Alexandar. The Mitki and the Art of Postmodern Protest in Russia (Julie A. Cassiday) 3:752

Mitchell, Rebecca. Nietzsche's Orphans. Music, Metaphysics, and the Twilight of the Russian Empire (Linda Edmondson) 1:249

Molisak, Alina. Żydowska Warszawa-żydowski Berlin. Literacki portret miasta w pierwszej połowie XX wieku (Bożena Shallcross) 1:238

Montgomery, David W. Practicing Islam: Knowledge, Experience, and Social Navigation in Kyrgyzstan (Nathan Light) 1:244

Moraski, Bryon J. and William R. Reisinger. The Regional Roots of Russia's Political Regime (Henry E. Hale) 3:859

Morley, Rachel. Performing Femininity: Woman as Performer in Early Russian Cinema (Olga Mesropova) 4:1127

Moroz, O. V., E. G. Lapina-Kratasyuk, and E. G. Nim, eds. Nastroika iazyka: Upravlenie kommunikatiiami na postsovetskom prostranstve (Lara RyazanovaClarke) 1:282

Morris, Jeremy. Everyday Post-Socialism: Working-Class Communities in the Russian Margins (Douglas Rogers) 2:555

Morrison, Kenneth. Sarajevo's Holiday Inn on the Frontline of Politics and War (Carole Rogel) 2:497
Mostowlansky, Till. Azan on the Moon: Entangling Modernity along Tajikistan's Pamir Highway (Russell Zanca) 3:822

Mrówczyński-Van Allen, Artur, Teresa Obolevitch, and Paweł Rojek, eds. Beyond Modernity: Russian Religious Philosophy and Post-Secularism (Randall A. Poole) 4:1131

Mullek, Magdalena, and Julia Sherwood, eds. and trans. Into the Spotlight: New Writing from Slovakia (Rajendra Chitnis) 3:816

Mureşan, Florin, Ladislau Gyémánt, Remus Câmpeanu, and Anton Dörner, eds. Conscripția fiscală a Transilvaniei din anul 1750 (Keith Hitchins) 1:225

Nagy, Zsolt. Great Expectations and Interwar Realities: Hungarian Cultural Diplomacy, 1918-1941 (Bennett Kovrig) 1:198

Napieralski, Bartosz. Political Catholicism and Euroscepticism: The Deviant Case of Poland in Comparative Perspective (Robert E. Alvis) 4:1059

Nefedov, Sergei Aleksanrovich. Uroven' zhizni naseleniia i agrarnoe razvitie Rossii v 1900-1940 godakh (Michael Ellman) 2:468

Neff, Severine, Maureen Carr, Gretchen Horlacher, and John Reef, eds., The Rite of Spring at 100 (Olga Haldey) 3:847

Nikolayenko, Olena. Youth Movements and Elections in Eastern Europe (Mischa Gabowitsch) 4:1097

Nim, E. G., E. G. Lapina-Kratasyuk, and O. V. Moroz, eds. Nastroika iazyka: Upravlenie kommunikatiiami na postsovetskom prostranstve (Lara RyazanovaClarke) 1:282

Norris, David A. Haunted Serbia: Representations of History and War in the Literary Imagination (Ralph Bogert) 2:510

Novikov, Anna, James Bjork, Tomasz Kamusella, and Tim Wilson, eds. Creating Nationality in Central Europe, 1800-1950: Modernity, Violence, and (Be)longing in Upper Silesia (Andrew Demshuk) 2:492

Nowicki, Wojciech. Salki, trans. Jan Pytalski (Benjamin Paloff) 3:813

Obolevitch, Teresa, Artur Mrówczyński-Van Allen, and Paweł Rojek, eds. Beyond Modernity: Russian Religious Philosophy and Post-Secularism (Randall A. Poole) 4:1131

Obradović, Biljana D. and Dubravka Djurić, eds. Cat Painters: An Anthology of Contemporary Serbian Poetry (Ellen Elias-Bursać) 1:241

Obradović, Dragana. Writing the Yugoslav Wars. Literature, Postmodernism, and the Ethics of Representation (Guido Snel) 1:242

Önol, Onur. The Tsar's Armenians: A Minority in Late Imperial Russia (Stephen B. Riegg) 4:1103

Orlich, Ileana Alexandra. Subversive Stages: Theater in Pre- and Post-Communist Hungary, Romania, and Bulgaria (Noel Witts) 4:1084

Orttung, Robert W., ed. Sustaining Russia's Arctic Cities: Resource Politics, Migration and Climate Change (Jonathan Oldfield) 2:553

Pallot, Judith and Elena Katz. Waiting at the Prison Gate: Women, Identity and the Russian Penal System (Julie Hansen) 2:540

Paloff, Benjamin. Lost in the Shadow of the Word: Space, Time, and Freedom in Interwar Eastern Europe (Michal Oklot) 4:1076

Parks, Jenifer. The Olympic Games, the Soviet Sports Bureaucracy, and the Cold War: Red Sport, Red Tape (Susan Grant) 1:274

Partan, Olga. Vagabonding Masks: The Italian Commedia Dell'arte in the Russian Artistic Imagination (Colleen McQuillen) 3:854 
Patyk, Lynn Ellen. Written in Blood: Revolutionary Terrorism and Russian Literary Culture, 1861-1881 (Christopher Ely) 4:1118

Peirce, Leslie. Empress of the East: How a European Slave Girl Became Queen of the Ottoman Empire (Kiril Petkov) 3:779

Pelkmans, Mathijs. Fragile Conviction: Changing Ideological Landscapes in Urban Kyrgyzstan (Noor O’Neill Borbieva) 3:821

Perabo, Betsy C. Orthodoxy and the Russo-Japanese War (Daniela Kalkandjieva) 4:1133

Peri, Alexis. The War Within: Diaries from the Siege of Leningrad (Martin J. Blackwell) 1:271

Perlina, Nina. Teksty-kartiny i ekfrazisy v romane Dostoevskogo "Idiot" (Stiliana Milkova) 2:543

Petrov, Jurij A., Dittmar Dahlmann, and Klaus Heller, eds. Protestanten und Altgläubige-Juden und Muslime: Die ethno-konfessionelle Struktur der russländischen Unternehmerschaft vor 1914 (Catherine Evtuhov) 2:528

Pil'shchikov, Igor' and Ian Levchenko, eds. Epokha "ostraneniia": Russkii formalizm i sovremennoe gumanitarnoe znanie. Kollektivnaia monografia (Tamara Brzostowska-Tereszkiewicz) 3:856

Platonov, Andrei. Fourteen Little Red Huts and Other Plays, Robert Chandler, ed., Trans. Robert Chandler, Jesse Irwin, and Susan Larson (Kevin Reese) 2:550

Plokhy, Serhii. The Man with the Poison Gun: A Cold War Spy Story (Emil Draitser) 1:232

Plokhy, Serhii. ed. The Future of the Past: New Perspec tives on Ukrainian History (Serhiy Bilenky) 2:481

Plokhy, Serhii. Lost Kingdom: The Quest for Empire and the Making of the Russian Nation from 1470 to the Present (Krishan Kumar) 3:828

Polit, Monika. Mordechaj Chaim Rumkowski-Wahrheit und Legende: "Meine jüdische Seele fürchtet den Tag des Gerichts nicht," trans. Heidemarie Petersen, Jürgen Hensel, and Małgorzata Sparenberg (Gordon J. Horwitz) 3:791

Popa, Ion. The Romanian Orthodox Church and the Holocaust (Roland Clark) 3:801

Porter, Jillian. Economies of Feeling: Russian Literature under Nicholas I (Claire Whitehead) 4:1117

Portmann, Alexandra. "The Time is out of Joint": Shakespeares Hamlet in den Ländern des ehemaligen Jugoslawien (Vladimir Zorić) 4:1082

Preindl, Nadia. Russische Kinderliteratur im europäischen Exil der Zwischenkriegszeit (Larissa Rudova) 1:281

Přibáň, Jiří. The Defence of Constitutionalism: The Czech Question in Post-national Europe (Rick Fawn) 4:1095

Prokhorov, Alexander and Elena Prokhorova. Film and Television Genres of the Late Soviet Era (Vlad Strukov) 2:547

Prokhorova, Elena and Alexander Prokhorov. Film and Television Genres of the Late Soviet Era (Vlad Strukov) 2:547

Prusin, Alexander. Serbia under the Swastika: A World War II Occupation (Ben Shepherd) 4:1065

Quenoy, Paul du. Alexander Serov and the Birth of the Russian Modern (Inna Naroditskaya) 1:275

Raab, Nigel. All Shook Up: The Shifting Soviet Response to Catastrophes, 1917-1991 (Andrew Jenks) 3:830

Radeljic, Branislav and Leandrit I. Mehmeti, eds. Kosovo and Serbia: Contested Options and Shared Consequences (David N. Gibbs) 2:517

Raikhel, Eugene. Governing Habits: Treating Alcoholism in the Post-Soviet Clinic (Michelle Parsons) 1:292

Rakhimzianov, Bulat Raimovich. Moskva i tatarskii mir: sotrudnichestvo i protivostoianie $v$ epokhu peremen, XV-XVI vv. (Mikhail Krom) 4:1100
Ramet, Sabrina P. The Catholic Church in Polish History from 966 to the Present (Jim Bjork) 4:1056

Reef, John, Severine Neff, Maureen Carr, and Gretchen Horlacher, eds. The Rite of Spring at 100 (Olga Haldey) 3:847

Reisinger, William R. and Bryon J. Moraski. The Regional Roots of Russia's Political Regime (Henry E. Hale) 3:859

Remy, Johannes. Brothers or Enemies: The Ukrainian National Movement and Russia, from the 1840 s to the 1870s (Olga Andriewsky) 1:227

Renner, Stephen. L. Broken Wings: The Hungarian Air Force, 1918-1945 (Reina Pennington) 2:489

Reuter, Ora John. The Origins of Dominant Parties. Building Authoritarian Institutions in Post-Soviet Russia (Graeme Gill) 2:558

Reyfman, Irina. How Russia Learned to Write: Literature and the Imperial Table of Ranks (Kelly Herold) 3:848

Reznik, Aleksandr. Trotskii i tovarishchii: Levaia oppozitsiia i politicheskaia kul' tura RKP(b) 1923-1924 (Christopher Read) 4:1111

Rindzevičiūtè, Eglè. The Power of Systems: How Policy Sciences Opened Up the Cold War World (Benjamin Peters) 4:1136

Rogacheva, Maria A. The Private World of Soviet Scientists from Stalin to Gorbachev (Benjamin Tromly) 3:837

Rohdewald, Stefan, Thomas M. Bohn, and Rayk Einax, eds. Vlad der Pfähler-Dracula: Tyrann oder Volkstribun? (Stephen W. Reinert) 3:805

Rojek, Paweł, Artur Mrówczyński-Van Allen, and Teresa Obolevitch, eds. Beyond Modernity: Russian Religious Philosophy and Post-Secularism (Randall A. Poole) 4:1131

Romaniello, Matthew P. and Tricia Starks, eds. Russian History through the Senses from 1700 to the Present (Sally West) 1:254

Röskau-Rydel, Isabel, Matthias Barelkowski, and Claudia Kraft, eds. Zwischen Geschlecht und $\mathrm{Na}$ tion. Interdependenzen und Interaktionen in der multiethnischen Gesellschaft Polens im 19. und 20. Jahrhundert (Robert Nelson) 1:226

Rosochinsky, Max and Oksana Maksymchuk, eds. Words for War: New Poems from Ukraine (Maria G. Rewakowicz) 4:1025

Rutar, Sabine and Katrin Boeckh, eds. The Wars of Yesterday: The Balkan Wars and the Emergence of Modern Military Conflict, 1912-1913 (John Paul Newman) 4:1041

Saehrendt, Christian. Kunst in Kampf für das "Sozialistische Weltsystem”: Auswärtige Kulturpolitik der DDR in Afrika un Nahost (Radoslav Yordanov) 4:1068

Saginadze, Ella. Reformator posle reform: S. Iu. Witte i rossiiskoe obshchestvo, 1906-1915 gody (Peter Waldron) 1:255

Salagean, Tudor. Transylvania in the Second Half of the Thirteenth Century. The Rise of the Congregational System (Borbala Zsuzsanna Török) 1:218

Schlögel, Karl. In Space We Read Time: On the History of Civilization and Geopolitics, trans. Gerrit Jackson (Benno Werlen) 3:776

Schmitt, Oliver Jens, ed. The Ottoman Conquest of the Balkans: Interpretations and Research Debates (Linda T. Darling) 1:216

Sedivy, Miroslav. Crisis among the Great Powers: The Concert of Europe and the Eastern Question (Katherine E. Fleming) 3:774

Seelig, Rachel. Strangers in Berlin: Modern Jewish Literature between East and West, 1919-1933 (Gennady Estraikh) 1:236 
Shargorodskii, Sergei and Evgenii Soshkin, eds. Gendelev: Stikhi. Proza. Poetika. Tekstologiia (Sabine Koller) 3:851

Shaw, Claire L. Deaf in the USSR: Marginality, Community, and Soviet Identity, 1917-1991 (Cassandra Hartblay) 3:765

Shelton, Joanne, Katharine Hodgson, and Alexandra Smith, eds. Twentieth-Century Russian Poetry: Reinventing the Canon (Marat Grinberg) 4:1123

Sherwood, Julia and Magdalena Mullek eds. and trans. Into the Spotlight: New Writing from Slovakia (Rajendra Chitnis) 3:816

Shestopal, Elena, ed. New Trends in Russian Political Mentality: Putin 3.0 (Elena Chebankova) 1:289

Shevelenko, Irina. Modernizm kak arkhaizm: Natsionalizm i poiski modernistskoi estetiki $v$ Rossii (Martha Kelly) 4:1119

Shirinian, George N. ed. Genocide in the Ottoman Empire: Armenians, Assyrians and Greeks, 1913-1923 (Fatma Muge Göçek) 4:1054

Shore, Marci. The Ukrainian Night: An Intimate History of Revolution (Olena Nikolayenko) 4:1075

Shternshis, Anna. When Sonia Met Boris: An Oral History of Jewish Life Under Stalin (Anna Kushkova) 3:839

Sifneos, Evrydiki. Imperial Odessa: Peoples, Spaces, Identities (Svetlana Natkovich) 4:1073

Sirotkina, Irina and Roger Smith, The Sixth Sense of the Avant-Garde: Dance, Kinaesthesia and the Arts in Revolutionary Russia (Tim Harte) 3:853

Sjöberg, Eric. The Making of the Greek Genocide: Contested Memories of the Ottoman Greek Catastrophe (Taner Akçam) 2:503

Smith, Alexandra, Joanne Shelton, and Katharine Hodgson, eds. Twentieth-Century Russian Poetry: Reinventing the Canon (Marat Grinberg) 4:1123

Smith, David J., ed. Latvia-A Work in Progress? 100 Years of State-and Nation-Building (Mark A. Jubulis) 3:799

Smith, Kathleen E. Moscow 1956: The Silenced Spring (Deborah A. Field) 1:273

Smith, Nicholas Ross. EU-Russian Relations and the Ukraine Crisis (Kataryna Wolczuk) 2:515

Smith, Roger and Irina Sirotkina. The Sixth Sense of the Avant-Garde: Dance, Kinaesthesia and the Arts in Revolutionary Russia (Tim Harte) 3:853

Smolnik, Franziska. Secessionist Rule: Protracted Conflict and the Configurations of Non-state Authority (Edward W. Walker) 3:824

Solov'ev, Vladimir. Gregory Yuri Glazov, ed. and trans. The Burning Bush: Writings on Jews and Judaism (Marina Kostalevsky) 1:277

Soshkin, Evgenii and Sergei Shargorodskii, eds. Gendelev: Stikhi. Proza. Poetika. Tekstologiia (Sabine Koller) 3:851

Sowiński, Paweł, Gwido Zlatkes, and Ann Frenkel, eds. Duplicator Underground: The Independent Publish ing Industry in Communist Poland 1976-89 (Joanna Wojdon) 3:788

Spahn, Susanne. Das Ukraine-Bild in Deutschland: Die Rolle der russischen Medien. Wie Russland die deutsche Öffentlichkeit beeinflusst (Jan Claas Behrends) 4:1137

Spector, Regine A. Order at the Bazaar: Power and Trade in Central Asia (Johan Engvall) 3:760

Stach, Stephan, Yvonne Kleinmann, and Tracie L. Wilson, eds. Religion in the Mirror of Law: Eastern European Perspectives from the Early Modern Period to 1939 (Barbara Skinner) 2:483

Starks, Tricia and Matthew P. Romaniello, eds. Russian History through the Senses from 1700 to the Present (Sally West) 1:254
Starnawski, Bartłomiej, Anna Artwińska, and Grzegorz Wołowiec, eds. Studies on Socialist Realism: The Polish View (Yvonne Pörzgen) 1:239

Starosta, Anita. Form and Instability: Eastern Europe, Literature, Postimperial Difference (George Gasyna) 4:1080

Stedman Jones, Gareth. Karl Marx: Greatness and Illusion (Lars T. Lih) 1:213

Stockdale, Melissa Kirschke. Mobilizing the Russian Nation: Patriotism and Citizenship in the First World War (Sean McMeekin) 1:257

Stohler, Ursula. Disrupted Idylls: Nature, Equality, and the Feminine in Sentimentalist Russian Women's Writing (Mariia Pospelova, Mariia Bolotnikova, and Anna Naumova), Trans. Emily Lygo (Hilde Hoogenboom) 2:542

Stolarik, M. Mark, ed. The Czech and Slovak Republics: Twenty Years of Independence, 1993-2013 (Cynthia J. Paces) 3:781

Holmes, Larry. Stalin's World War II Evacuations: Triumph and Troubles in Kirov (Paul Stronski) 4:1108

Stubbs, Paul, Roy Archer, and Igor Duda, eds. Social Inequalities and Discontent in Yugoslav Socialism (Andreja Vezovnik) 1:230

Surdu, Mihai. Those Who Count: Expert Practices of Roma Classification (David M. Crowe) 2:471

Suslov, Mikhail and Mark Bassin, eds. Eurasia 2.0: Russian Geopolitics in the Age of New Media (Robert A. Saunders) 1:286

Swanson, John C. Tangible Belonging: Negotiating Germanness in Twentieth-Century Hungary (Peter Thaler) 1:223

Szczypien, Jean M. "Sailing towards Poland" with Joseph Conrad (David Mulry) 2:507

Szende, Katalin and Gerhard Jaritz, eds. Medieval East Central Europe in a Comparative Perspective: From Frontier Zones to Lands in Focus (Piotr Górecki) 1:220

Tasar, Eren. Soviet and Muslim: The Institutionalization of Islam in Central Asia (Adeeb Khalid) 4:1035

Taki, Victor. Tsar and Sultan: Russian Encounters with the Ottoman Empire (Charles Steinwedel) 2:526

Thaidigsmann, Karoline, Urs Heftrich, Robert Jacobs, and Bettina Kaibach, eds. Images of Rupture between East and West: The Perception of Auschwitz and Hiroshima in Eastern European Arts and Media (Irena Grudzińska Gross) 3:812

Timmer, Andria D. Educating the Hungarian Roma. Nongovernmental Organizations and Minority Rights (Stefánia Toma) 1:247

Toal, Gerard. Near Abroad: Putin, the West, and the Contest over Ukraine and the Caucasus (Viacheslav Morozov) 3:858

Tochka, Nicholas. Audible States: Socialist Politics and Popular Music in Albania (Ljerka V. Rasmussen) 3:809

Tomić, Svetlana. Doprinosi nepoznate elite: Mogućnosti sasvim drugačije budućnosti (Iskra Iveljić) 2:509

Tönsmann, Susanne. What is Citizenship for? Citizenship and Naturalization in Latvia (Mark A. Jubulis) 3:799

Turoma, Sanna, Birgit Beumers, Alexander Etkind, and Olga Gurova, eds. Cultural Forms of Protest in Russia (Julie A. Cassiday) 3:752

Tychyna, Pavlo. The Complete Early Poetry Collections, trans. Michael M. Naydan (Alessandro Achilli) 3:817

Unkovski-Korica, Vladimir. The Economic Struggle for Power in Tito's Yugoslavia: From World War II to Non-Alignment (John K. Cox) 4:1069

Varga, Bálint. The Monumental Nation: Magyar Nationalism and Symbolic Politics in Fin-de-siècle Hungary (John C. Swanson) 3:783 
Vásárhelyi, Júlia and Bálint Magyar, eds. Twenty-Five Sides of a Post-communist Mafia State, trans. Bálint Bethlenfalvy, Steven Nelson, Kata Paulin, Ágnes Simon, Anna Szemere, Robert Young, and Frank T. Zsigó (Andrew Felkay) 3:825

Vasilyeva, Nataliya A. and Maria L. Lagutina, The Russian Project of Eurasian Integration: Geopolitical Prospects (Alexander Libman) 1:287

Vatlin, Alexander. Ed. and Trans. Seth Bernstein. Agents of Terror: Ordinary Men and Extraordinary Violence in Stalin's Secret Police (Golfo Alexopoulos) 1:264

Vinokur, Val, ed. and trans., Isaac Babel: The Essential Fictions (Mikhail Krutikov) 4:1121

Viola, Lynne. Stalinist Perpetrators on Trial: Scenes From the Great Terror in Soviet Ukraine (Jeffrey W. Jones) 3:769

Voskresenskii, N. A. Petr Velikii kak Zakonodatel': Issledovanie zakonodatel' nogo protsessa $v$ Rossii $v$ epokhu reform pervoi chetverti XVIII veka, D. O. Serova, ed. (Sergei Antonov) 2:522

Weiss, Jan. The House of a Thousand Floors, trans. Alexandra Büchler (Alfred Thomas) 2:512

Weiss-Wendt, Anton. The Soviet Union and the Gutting of the UN Genocide Convention (Mark Hurst) 4:1134

Westad, Odd Arne. The Cold War: A World History (Tobias Rupprecht) 3:777

Wezel, Katja. Geschichte als Politikum: Lettland und die Aufarbeitung nach der Diktatur (Deniss Hanovs) 3:798

Willimott, Andy. Living the Revolution: Urban Communes and Soviet Socialism, 1917-1932 (Steven E. Harris) 1:261
Wilson, Tim, James Bjork, Tomasz Kamusella, and Anna Novikov, eds. Creating Nationality in Central Europe, 1800-1950: Modernity, Violence, and (Be) longing in Upper Silesia (Andrew Demshuk) 2:492

Wilson, Tracie L., Yvonne Kleinmann, and Stephan Stach, eds. Religion in the Mirror of Law: Eastern European Perspectives from the Early Modern Period to 1939 (Barbara Skinner) 2:483

Wingfield, Nancy M. The World of Prostitution in Late Imperial Austria (Sharon A. Kowalsky) 4:1060

Wołowiec, Grzegorz, Anna Artwińska, and Bartłomiej Starnawski, eds. Studies on Socialist Realism: The Polish View (Yvonne Pörzgen) 1:239

Yarov, Sergey. Leningrad 1941-42: Morality in a City Under Siege (Polina Barskova) 4:1110

Yordanov, Radoslav R. The Soviet Union and the Horn of Africa during the Cold War: Between Ideology and Pragmatism (Andreas Hilger) 2:474

Zakić, Mirna. Ethnic Germans and National Socialism in Yugoslavia in World War II (Emily Greble) 3:

Zamiatin, Dmitrii. Gunny v Parizhe: K metageografii russkoi ku' ltury (Lida Oukaderova) 3:843

Zhuk, Sergei I. Nikolai Bolkhovitinov and American Studies in the USSR: People's Diplomacy in the Cold War (Eric Shiraev) 4:1112

Zlatkes, Gwido, Paweł Sowiński, and Ann Frenkel, eds. Duplicator Underground: The Independent Publishing Industry in Communist Poland 1976-89 (Joanna Wojdon) 3:788

Žukienė, Rasutė and Giedrẻ Jankevičiūtè, eds. The Art of Identity and Memory: Toward a Cultural History of the Two World Wars in Lithuania (Michelle R. Viise) 3:784 